Valóságos könyvtár - könyvtári valóság. Könyvtár- és információtudományi tanulmányok 2018. Szerk. Kiszl Péter, Csík Tibor.

Budapest, ELTE BTK Könyvtár- és Információtudományi Intézet. 2018. 199-206.

\title{
TÖBBNYELVÜ KERESÉSI LEHETŐSÉGEK AZ ONLINE KÖNYVTÁRI KATALÓGUSOKBAN
}

\author{
NÉMETH KATALIN
}

ELTE BTK KITI, egyetemi adjunktus

\section{TARTALMI ÖSSZEGFOGLALÓ}

Számos magyarországi könyvtár rendelkezik jelentős idegen nyelvű gyűjteménnyel, melyek között különböző írásrendszerű dokumentumok is megtalálhatók. Az integrált könyvtári rendszerek nyújtotta lehetőségek megkönnyítik ezen dokumentumok feldolgozását és visszakeresését, így az ELTE Egyetemi Könyvtár multiszkript rekordjai, melyek elsősorban a Távol-keleti Intézet és a Konfuciusz Intézet köteteinek bibliográfiai leírásait teszik elérhetővé és kereshetővé eredeti kínai, japán és koreai írásrendszerben is. A legelterjedtebb hazai gyakorlat azonban a leggyakrabban keresett adatelemek, például a szerzői nevek utalókkal való kiegészítése, amely jellemzően a transzliterálás szabványai alapján létrehozott egységesített adat mellé rendel egyéb, latin betűs névformákat. A tanulmány a Hazai György Könyvtár köteteinek katalogizálása során felmerült kérdéseket, az idegen nyelvủ dokumentumok feltárásának és megjelenítésének lehetőségeit vizsgálja, különös tekintettel a felhasználói igényekre.

A 2016-ban elhunyt turkológus, orientalista, egyetemi tanár, az MTA rendes tagja, Hazai György (1932-2016) lánya, Hazai Kinga azzal a kéréssel kereste meg az Eötvös Loránd Tudományegyetem Bölcsészettudományi Karának Könyvtár- és Információtudományi Intézetét, hogy segítsenek apja egyedülálló gyűjteményének rendezésében és feltárásában. A munka 2017 januárjában kezdődött meg informatikus könyvtáros, valamint turkológus hallgatókkal. A 280 doboznyi dokumentum átválogatása után, melynek eredményeként a duplumokat az edinburgh-i St. Andrews Egyetem és az Azerbajdzsáni Akadémia Központi Könyvtára kapta meg, ugyanezen év márciustól a katalogizálás is elindulhatott a Monguz Kft. által fejlesztett Qulto integrált könyvtári rendszer segítségével. ${ }^{1}$ A Hazai György Könyvtár végül 2017. május 25-én nyílt meg Budapesten a Közraktár utcában. ${ }^{2}$

\section{Nyelvi sokeféleség}

A Hazai Könyvtár állománya nyelvileg rendkívül heterogén, ami a feldolgozást és a viszszakereshetővé tételt is nehezíti. Mivel számos magyarországi könyvtár rendelkezik jelentôs idegen nyelvű gyűjteménnyel, melyek között különböző írásrendszerű dokumentumok is megtalálhatók, így érdemes megvizsgálni, hogy az egyes könyvtárak hogyan 


\section{NÉMETH KATALIN}

képesek ezeket az idegen nyelvű anyagokat a felhasználók számára a leghatékonyabb módon elérhetővé tenni és szolgáltatni. A több mint tízezer kötetes Hazai György Könyvtár katalógusában 2018 januárjában 8300 rekord szerepelt, melyek például cirill karakterekkel is kereshetók. Az 1. táblázatban látható, hogy a könyvtárban, mint turkológiai szakgyüjteményben a török nyelvű dokumentumok aránya a legnagyobb, de emellett számos más nyelv is megtalálható, melyek közül néhányat mindössze egy-egy kötet képvisel.

1. tábláąat

Idegen nyelveke a Hazai György Kömyvtárban

\begin{tabular}{|l|l|c|l|l|c|}
\hline Nyelv & $\begin{array}{c}\text { Dokumentumok } \\
\text { száma }\end{array}$ & & \multicolumn{1}{|c|}{ Nyelv } & $\begin{array}{c}\text { Dokumentumok } \\
\text { száma }\end{array}$ \\
\hline 1. & albán & 8 & 11. & kirgíz & 37 \\
\hline 2. & arab & 77 & 12. & kumük & 1 \\
\hline 3. & azeri & 266 & 13. & magyar & 412 \\
\hline 4. & baskír & 9 & 14. & orosz & 1305 \\
\hline 5. & bolgár & 102 & 15. & örmény & 1 \\
\hline 6. & csagatáj & 5 & 16. & oszmán & 268 \\
\hline 7. & csuvas & 10 & 17. & török & 3477 \\
\hline 8. & grúz & 30 & 18. & türkmén & 43 \\
\hline 9. & karakalpak & 3 & 19. & ujgur & 16 \\
\hline 10. & kazah & 72 & 20. & üzbég & 122 \\
\hline
\end{tabular}

A török nyelv karakterkészlete hasonló a magyarhoz Mustafa Kemal Atatürk 1928-as reformja óta, azonban van néhány mellékjeles mássalhangzó, mint a $\varrho$, 乌̆ és az s, valamint érdekes a kétféle $i$ (I és I) használata is. ${ }^{3}$ A veláris $i$ például gyakran okoz nehézséget az online keresések alkalmával különösen a karakterérzékeny rendszereknél, bár ezt több integrált rendszer képes már megfelelően kezelni. A török város angol és török neve között írásban épp egyetlen $i$ a különbség: Istanbul (angol) és İstanbul (török).

Szinte minden könyvtárban kihívást jelent a cirill betús kötetek feldolgozása, mivel számos különböző nyelv használja a cirill karaktereket, azonban több eltérés is megfigyelhető az egyes nyelvek karakterkészletei között, amelyek még a XX. században is többször módosultak. Mivel nem mindig van lehetőség arra, hogy a nyelveket és írásrendszereket pontosan ismerő és felismerő könyvtárosok végezzék a feldolgozást, a nyelv azonosítását a dokumentumok megjelenési helye mellett épp az említett eltérések könnyítik meg, miközben arra is figyelni kell, hogy mikor jelent meg az adott kötet, mivel a XX. században az írásrendszerek akár néhány évtizeden belül is változhattak. Noha a cirill karakterek transzliterációját szabvány ${ }^{4}$ határozza meg, azonban - bár feltételezhető lenne, hogy a szláv kötetekkel kapcsolatban következetes és egységes leírásokat találunk - 
még azokban a könyvtárakban sincs könnyű dolguk a felhasználóknak, ahol tudatosan alkalmazzák és betartják a szabvány előírásait. A magyar olvasók ugyanis megszokták a fonetikus átírást, a transzszkripciót, mely tükröz néhány kiejtési sajátságot, mint például a mássalhangzók lágyulását ${ }^{5}$, ezért is nélkülözhetetlen az utalók használata.

A 2. táblázat egy konkrét kötet, a Sait Faik (1906-1954) török íróról és műveiről szóló könyv ${ }^{6}$ néhány bibliográfiai adatának leírását mutatja be online katalógusok példáján keresztül. A Magyar Tudományos Akadémia Könyvtára ${ }^{7}$, a német közös katalógus ${ }^{8}$ és az angol szakkönyvtári közös katalógus ${ }^{9}$ következetes az ISO 9 szerinti átírásban a cím esetében, azonban a szerző neve már eltérő formában olvasható. A British Library ${ }^{10}$ a címet és a megjelenési adatokat cirill karakterekkel rögzítette, azonban latin karakterekkel is kereshetővé tette. A legteljesebb megoldást a francia egyetemi hálózat ${ }^{11}$ kínálja, amely a címet, a szerzőt és a megjelenési adatokat is közli cirill, valamint latin karakterekkel egyaránt. Az öt katalógusból mindössze kettô veszi fel a török író, Sait Faik nevét tárgyi melléktételként.

\section{2. táblázat}

Orosz. nyelvü könyv átírása nemzetközi katalógusokban

\begin{tabular}{|c|c|c|c|c|}
\hline & Cím & Szerző & Megjelenés & Egyéb név \\
\hline $\begin{array}{l}\text { MTAK (Magyar } \\
\text { Tudományos } \\
\text { Akadémia Könyv- } \\
\text { tár és Információs } \\
\text { Központ) }\end{array}$ & $\begin{array}{l}\text { Said Faik i } \\
\text { ego novelly }\end{array}$ & $\begin{array}{l}\text { Ajzenštein, Natta } \\
\text { Avrumovna }\end{array}$ & $\begin{array}{l}\text { Moskva : Nauka, } \\
1971\end{array}$ & \\
\hline British Library & $\begin{array}{l}\text { Саил Фаик } \\
\text { и его но- } \\
\text { велмы.. }\end{array}$ & $\begin{array}{l}\text { AIZENSHTEIN, } \\
\text { Natal'ya } \\
\text { Avraamovna }\end{array}$ & $\begin{array}{l}\text { Москва : Изда- } \\
\text { тельство “Наука", } \\
\text { ГАавная редакция } \\
\text { восточной Аите- } \\
\text { ратуры, } 1971 .\end{array}$ & FAİK, Said. \\
\hline $\begin{array}{l}\text { COPAC (Copac } \\
\text { National, } \\
\text { Academic and } \\
\text { Specialist Library } \\
\text { Catalogue) } \\
\end{array}$ & $\begin{array}{l}\text { Said Faik i } \\
\text { ego novelly }\end{array}$ & $\begin{array}{l}\text { Aĭzenshteĭn, N. A. } \\
\text { (Natal'ıa Avraamov- } \\
\text { na) } 1923\end{array}$ & $\begin{array}{l}\text { Moskva : "Nauka" } \\
1971\end{array}$ & $\begin{array}{l}\text { Sait Faik } \\
1906-1954\end{array}$ \\
\hline $\begin{array}{l}\text { GVK } \\
\text { (Gemeinsamer } \\
\text { Verbundkatalog) } \\
\end{array}$ & $\begin{array}{l}\text { Said Faik i } \\
\text { ego novelly }\end{array}$ & $\begin{array}{l}\text { Ajzenštejn, Natal'ja } \\
\text { Avraamovna }\end{array}$ & $\begin{array}{l}\text { Moskva : Izd. } \\
\text { Nauka, } 1971\end{array}$ & \\
\hline $\begin{array}{l}\text { SUDOC } \\
\text { (Système } \\
\text { Universitaire de } \\
\text { Documentation) }\end{array}$ & $\begin{array}{l}\text { Саил Фаик } \\
\text { и его } \\
\text { новелцы - } \\
\text { Said Faik i } \\
\text { ego novelly }\end{array}$ & $\begin{array}{l}\text { Айзенштейн, } \\
\text { Натта Аврумовна } \\
\text { - Ajzenštejn, Natta } \\
\text { Avrumovna }\end{array}$ & $\begin{array}{l}\text { Москва : "Наука", } \\
1971 \text { - Moskva : } \\
\text { "Nauka", } 1971\end{array}$ & \\
\hline
\end{tabular}




\section{NÉMETH KATALIN}

A könyvtári katalógusok másik nyelvi kérdése alapvetően a tárgyszavakkal kapcsolatban jelentkezik a felhasználói célcsoportok differenciálásával. Kiknek, milyen anyanyelvú vagy milyen nyelvtudással rendelkező olvasók számára kínálja dokumentumait az adott könyvtár. Az Eötvös Loránd Tudományegyetem Angol-Amerikanisztikai Intézet Könyvtára ${ }^{12}$ az amerikai Kongresszusi Könyvtár angol tárgyszavait használja, azonban számos magyar tárgyszó is található a katalógusukban. Az ELTE Germanisztikai Intézet Könyvtára hasonlóképp magyar és német tárgyszavakkal dolgozik, azonban egyik sem használja folyamatosan a kifejezéseket mindkét nyelven párhuzamosan. Az Andrássy Gyula Budapesti Német Nyelvű Egyetemen ${ }^{13}$, ahol az oktatás nyelve a legtöbb kurzus esetében is a német, a könyvtári katalógus tárgyszavai között is elsősorban német kifejezéseket találunk, bár néhol angol szavak is előfordulnak, jellemzően a más katalógusból importált rekordok esetében, de mindenképp következetes a könyvtár a tárgyszavak tekintetében. A 3. táblázat az Andrássy Egyetem néhány tárgyszavának nyelvi megjelenését mutatja be.

\section{3. táblázat}

Az. Andrássy Egyetem tárgyszavainak, nyelve

\begin{tabular}{|l|c|c|c|}
\hline Tárgyszó & magyar & német & angol \\
\hline gazdaság & 1 & 501 & 10 \\
\hline jog, jogtudomány & 0 & 766 & 11 \\
\hline politika & 0 & 900 & 8 \\
\hline szociológia & 0 & 252 & 1 \\
\hline történelem & 0 & 3855 & 9 \\
\hline
\end{tabular}

A Hazai György Könyvtár a Hazai György Orientalisztikai Alapítvány támogatásával valósulhatott meg, melynek kuratóriumi elnöke Fodor Pál, a Magyar Tudományos Akadémia (MTA) Bölcsészettudományi Kutatóközpontjának főigazgatója, a kuratórium tagjai továbbá Barbara Kellner-Heineke, a Freie Universität Berlin professzora és Hóvári János, a Károli Gáspár Református Egyetem oktatója, a Magyar Alkotómúvészeti Közhasznú Nonprofit Kft. (MANK) főigazgatója. Az alapítvány mellett számos más szervezet és magánszemély segíti a kezdeményezést, hogy a szakkönyvtár a turkológiával foglalkozó nemcsak hazai, hanem külföldi szakemberek számára is magas szintû szolgáltatásokat nyújthasson. A nemzetközi nyitás egyik alapfeltétele a gyújtemény és az információk hozzáférhetővé tétele minél több nyelven. Ezt a célt szolgálja, hogy a honlap kezdettől fogva angolul is elérhető, a könyvtári katalógus viszont párhuzamosan három nyelven, magyarul, angolul és törökül is használható. Az integrált könyvtári rendszer, a Qulto online katalógusának felülete magyar, angol, német, román és török nyelvű, a keresés alapértelmezett nyelve az angol. Az egyes authority fájlok angol nyelvűek. Az eredményes keresés egyik feltétele, hogy a személynév mindig ugyanabban az egységes, 
szabványos alakban kerüljön a katalógusba, ${ }^{14}$ de mindez igaz a földrajzi nevekre, valamint a tárgyszavakra is.

A katalógus angol nyelve adta a lehetőséget a Library of Congress tárgyszórendszerének átvételére azért is, mert az online elérhető török katalógusok ${ }^{15}$, melyekben a Hazai Könyvtár állományának egy része megtalálható, nem minden esetben rendeltek tárgyszavakat a dokumentumokhoz, és sok esetben a rekordok importálása sem jelentett megoldást az esetleges utómunkálatok, javítások miatt.

A Budapesti Gazdasági Egyetem (BGE) Külkereskedelmi Kar Könyvtárában használt Textlib ${ }^{16}$ online katalógus két szempontból is figyelmet érdemel. A keresőmotorokhoz hasonlóan próbálja javítani a felhasználók keresőkifejezéseiben előforduló esetleges helyesírási hibákat. Például, ha Kotlertől szeretnénk dokumentumot, de nem emlékszünk a mú címére, vagy épp arra vagyunk kíváncsiak, hogy mi található meg a szerzőtől a könyvtárban, akkor csak a szerző nevére hagyatkozhatunk, azonban előfordulhat, hogy véletlenül elírjuk a nevet, és a Kotler helyett Ktolert gépelünk. Ha nem adtuk meg, hogy pontosan hol keressen - esetünkben a szerző nevében - akkor a program ellenőrzi a katalógusban előforduló összes hasonló írásképpel rendelkező kifejezést a címekben, személynevekben stb. Végül kapunk egy listát arról, hogy az „utolér” és „kotler” szavak előfordulnak címekben, míg szerzőként kizárólag a „kotler” szerepel. Ha a „Ktoler” formát a szerzők között keressük, a program javaslatot tesz a „kotler” változatra, amellyel már valóban lesz találatunk. Rendkívül hasznos funkció, hiszen a csonkolás és a helyettesítő karakterek használata nem mindig segít gyorsan releváns találathoz jutni, és jelenleg a könyvtári katalógusok jellemzően karakterérzékenyek.

A másik hasznos funkció, ami a könyvtárosok lelkiismeretes munkáját dicséri a BGE könyvtárában, az egyes dokumentumok adatainak közismert címmel való ellátása. A felhasználók gyakran emlegetnek köteteket egymás között fiktív, saját maguk által kitalált címekkel, melyet később egyre többen használnak, ahogy történt ez a hat kötetes, Sötér István szerkesztésében megjelent A magyar irodalom története ${ }^{17}$ című kiadvánnyal is, melyet a borító színe miatt évtizedeken keresztül a „Spenót” szóval jellemeztek. A BGE katalógusában például szerepelnek ezek a címváltozatok is, így a felhasználók ezekkel is tudnak keresni. A Hazai György Könyvtárban számos irodalomtörténeti kötet, valamint irodalmi forráskiadás megtalálható, melyek feldolgozása az idegennyelvú dokumentumokkal kapcsolatban felvetett még egy kérdést. Az egységesített cím vagy eredeti cím biztosítja, hogy egy mű különböző nyelvű fordításait egyetlen kereséssel ki tudjuk listáztatni a katalógusban. Ez akkor is múködik, ha a cím tárgyi melléktételként szerepel, hiszen így megtalálhatunk minden, a keresett múről szóló elemzést. Probléma akkor van, ha az eredeti cím nem ismert a felhasználó számára vagy nehézséget okoz az eredeti cím helyesírása. Szemléletes példát kínálnak erre a Hazai Könyvtár Aranyfény szutráról ${ }^{18}$ szóló, valamint a kirgíz eposz, a Manas ${ }^{19}$ kötetei. 
4. táblázat

Az. Aranyfény szutra és Manasz kötetek cimváltozatai

\begin{tabular}{|c|c|c|c|}
\hline Nyelv & Cím & Nyelv & Cím \\
\hline magyar & Aranyfény-szutra & magyar & Manasz \\
\hline angol & $\begin{array}{l}\text { Golden Light Sutra; } \\
\text { Sutra of Golden Light }\end{array}$ & angol & Epic of Manas \\
\hline német & $\begin{array}{l}\text { Goldglanz Sutra; } \\
\text { Sutra vom goldenen Licht }\end{array}$ & német & Manas-Epos \\
\hline francia ${ }^{20}$ & $\begin{array}{l}\text { Sûtra de la lumière dorée; } \\
\text { Sûtra de la radiance d'or; } \\
\text { Sûtra du suprême éclat d'or; }\end{array}$ & francia & $\begin{array}{l}\text { Cycle de Manas; } \\
\text { Manas : épopée kirghize }\end{array}$ \\
\hline szanszkrit & सुवर्णप्रभासोत्तमसूत्रेन्द्रराज & kirgíz (arab) & ماناس دستانى \\
\hline szanszkrit $^{21}$ & $\begin{array}{l}\text { Suvarnaprabhasottamasutra; Suv } \\
\text { arṇaprabhāsottamasūtrendrarāja }\end{array}$ & kirgíz (cirill) & Манас дастаны \\
\hline $\begin{array}{l}\text { szanszkrit } \\
\left(\text { IAST }^{22} \text { ) }\right.\end{array}$ & $\begin{array}{l}\text { Suvarnaprabhāsottamasūtrendra } \\
\text { rājaḥ }\end{array}$ & török & Manas Destan1 \\
\hline
\end{tabular}

A 4. táblázałban olvasható az Aranyfény szutra cím szanszkrit, valamint az európai nyelvek közül angol - mint a Hazai Könyvtár katalógusának nyelve -, francia és német nyelvű alakja. A Francia Nemzeti Könyvtár (Bibliothèque nationale de France, BnF) szerzőkről, címekrôl és témákról szóló adatbázisában megtaláljuk ezt a címet is négy francia változatban, valamint a számos keleti nyelvú variáns is segíti az olvasót az általa keresett mű megtalálásában. A 4. táblázatban a másik példa a kirgíz nyelvű Manasz eposz, mely a kirgíz nyelv problematikájára is felhívja a figyelmet, mivel számos átírási rendszert használnak világszerte, melyek több karakter esetében is eltérést mutatnak. Ilyen például az American Library Association (ALA) és a Library of Congress (LC) ${ }^{23}$ szabályzata, vagy a földrajzi nevek egységesítésére létrehozott névtér, a United States Board on Geographic Names (BGN) és a Permanent Committee on Geographical Names for British Official Use (PCGN) ${ }^{24}$ előírásai, vagy a korábban már említett ISO 9. A magyarországi gyakorlat az ISO szerinti átírást követi, de továbbra is hangsúlyozzuk, hogy a felhasználót is tájékoztatni és segíteni kell, hogy ismerje a leghatékonyabb keresési stratégiákat. Az Országos Idegennyelvű Könyvtár amellett, hogy számos utalóval biztosítja az egyes authority fájlok elérését, az online katalógus nyitólapján segédlet ${ }^{25}$ is található a cirill és görög nyelvű dokumentumok kereséséhez.

\section{Megoldási lehetöségek}

Az integrált könyvtári rendszerek nyújtotta lehetőségek között az egyik megoldást az ALEPH multiszkript rekordjai kínálják, melyeket például az ELTE Egyetemi Könyvtár 
is használt, amikor a Távol-keleti Intézet és a Konfuciusz Intézet köteteinek bibliográfiai leírásait tette elérhetővé és kereshetővé eredeti kínai, japán és koreai írásrendszerben is. Az UNICODE alapú rendszerben a tartalom és az interfész megjelenítésére is több mint húsz nyelven van lehetőség. ${ }^{26} \mathrm{Az}$ ALEPH online katalógusának kezdőlapján ${ }^{27}$ lehetőség van az eltérő írásrendszerek használatához speciális karaktereket választani, azonban ehhez szükség van az eszközünkre telepített megfelelő fontkészletekre is a helyes megjelenítéshez. A Qulto integrált könyvtári rendszer például szintén lehetővé tesz rekordfordításokat, ami akkor múködik hatékonyan, ha megfelelő a rekord minden adata, és pontos szabályok szerint történik az egyes adatelemek adott nyelvre fordítása.

A legelterjedtebb hazai gyakorlat jelenleg a leggyakrabban keresett adatelemek, például a szerzői nevek utalókkal való kiegészítése, amely jellemzően a transzliterálás szabványai alapján létrehozott egységesített adat mellé rendel egyéb, latin betûs névformákat. Az utalókra mindenképp szükség van a katalógusokban minél több adattípus esetében, így például a címekkel kapcsolatban is. Hosszabb távon azonban megoldást jelenthet a könyvtári katalógusok összekapcsolása a web egyéb keresőmotorjaival, valamint adatbázisaival, a szemantikus web és a linked data (kapcsolt adat) technológiák, amelyek elősegíthetik az eltérő írásrendszerű dokumentumok hatékonyabb keresését is.

\section{Jegyzetek}

1. Hazai György Könyvtár. Forrás: http:/ /www.hazaigyorgy.com/konyvtar [2018. január 10.]

2. TAKÁCS Erzsébet: Könyvtár a turkológia szolgálatában. Forrás: www.kultura.hu/konyvtarturkologia [2018. január 4.]

3. LEWIS, Geoffrey: The turkish language reform. A catastrophic success. Oxford, Oxford University Press, 1999. 27-37. p.

4. MSZ ISO 9:1997 Információ és dokumentáció. A cirill karakterek transzliterációja latin karakterekre. Szláv és nem szláv nyelvek. [Budapest], Magyar Szabványügyi Test., 1997. 15 p.

5. KEMÉNY Gábor: A nem latin betűs írású nyelvek neveinek magyar helyesírásáról. In: Kemény Gábor: A nyelvtől a stílusig. Budapest, Tinta Könyvkiadó, 2010. 77. p.

6. AJZENŠTEJN, Natta Avrumovna: Said Faik i ego novelly. Moscow, Izdat. „Nauka”, 1971. $238 \mathrm{p}$.

7. Magyar Tudományos Akadémia Könyvtárának katalógusa. Forrás: opac.mtak.hu [2018. január 15.]

8. Gemeinsamer Verbundkatalog. Forrás: https://gso.gbv.de [2018. január 15.]

9. Copac National, Academic and Specialist Library Catalogue. Forrás: http://copac.jisc.ac.uk/ [2018. január 15.]

10. British Library Catalogue. Forrás: http://explore.bl.uk/primo_library/libweb [2018. január 15.]

11. Catalogue Système Universitaire de Documentation. Forrás: www.sudoc.abes.fr [2018. január 15.]

12. ELTE EKSZ katalógusa. Forrás: http://aleph.elte.hu [2018. január 15.]

13. Andrássy Gyula Budapesti Német Nyelvű Egyetem Egyetemi Könyvtár katalógusa. Forrás: http://aleph-36ane.hosted.exlibrisgroup.com:8991/F?func=find-b-0\&local_base= ane01\&con_lng=hun [2018. január 15.] 


\section{NÉMETH KATALIN}

14. KÖNTÖS Nelli: Szerzők nyomában. A könyvtári szabványok szerepe az intézményi publikációs adattárak névkezelési stratégiájában. = Könyvtári Figyelő, 58. évf. 2. sz. 2012. 255-279. p.

15. TO-KAT, török közös katalógus. Forrás: http://www.toplukatalog.gov.tr [2018. január 31.]

16. Budapesti Gazdasági Egyetem Külkereskedelmi Kar Könyvtárának katalógusa. Forrás: http://tlwww.kkf.hu/ [2018. január 20.]

17. SŐTÉR István (szerk.): A magyar irodalom története. I-VI. kötet. Budapest, Akadémiai Kiadó, 1964-1966.

18. Például: RADLOFF, W. (Hrsg.): Suvarnaprabhasa: das Goldglanz-Sutra. I-III. Osnabrück, Biblio Verlag, 1970. és ZIEME, Peter (Hrsg.): Altun Yaruq Sudur: Vorworte und das erste Buch : Edition und Übersetzung der alttürkischen Version des Goldglanzsutra : Suvarnṇaprabhs̄ottamasūtra : mit 139 Abbildung auf 88 Tafeln. Berlin, Akademie-Verlag, 1996.

19. Például: LIPKIN, Semen Izrailevič (Bearb.): Manas der Hochherzige: kirgisisches Heldenepos. Berlin, Verlag Volt und Welt Berlin, 1974. és YILDIZ, Naciye: Manas destani (W. Radloff) ve kirgiz kültürü ile ilgili tespit ve tahliller. Ankara, Türk Dil Kurumu, 1995.

20. A Bibliothèque nationale de France adatbázisa a szerzőkről, a címekről és a témákról. Forrás: http:// data.bnf.fr [2018. január 25.]

21. ISO 15919:2001 Information and documentation. Transliteration of Devanagari and related Indic scripts into Latin characters Geneva, ISO, 2001.

22. International Alphabet of Sanskrit Transliteration.

23. ALA-LC transzliterációs szabályzatok. Forrás: https://www.loc.gov/catdir/cpso/roman. html [2018. január 31.]

24. BGN/PCGN transzliterációs szabályzatok. Forrás: http://geonames.nga.mil/gns/html/ romanization.html [2018. január 31.]

25. OIK katalógus. Forrás: https://www.oik.hu/monguz/index.jsp?page=search [2018. január 31.]

26. ÉZSIÁS Anikó - MAJOR Kornélia - SZÉKELYNÉ TÖRÖK Tünde: Multiscript rekordok az ALEPH integrált könyvtári rendszerben: közös katalógus építése az ELTE Egyetemi Könyvtári Szolgálatában. = Tudományos és Műszaki Tájékoztatás, 59. évf. 11-12. sz. 2012. 497-509. p.

27. ELTE EKSZ katalógusa. Forrás: http://aleph.elte.hu [2018. január 15.]

Németh Katalin egyetemi adjunktus, az ELTE BTK Könyvtár- és Információtudományi Intézetének oktatásfelelőse, a Magyar Könyvtárosok Egyesületének tagja. Kutatási területe: domonkos könyvkultúra, könyvtári menedzsment, ügyfélkapcsolat-menedzsment. 